United States

Environmental Protection

Agency

Office of Radiation Programs
Eastern Environmental

Radiation Facility

1890 Federal Drive

Montgomery, AL 36109
EPA 520/5-88-018

June 1989

\title{
Radiation
}

\section{Radiological Survey of the Mare Island Naval Shipyard, Alameda Naval Air Station, and Hunters Point Shipyard}
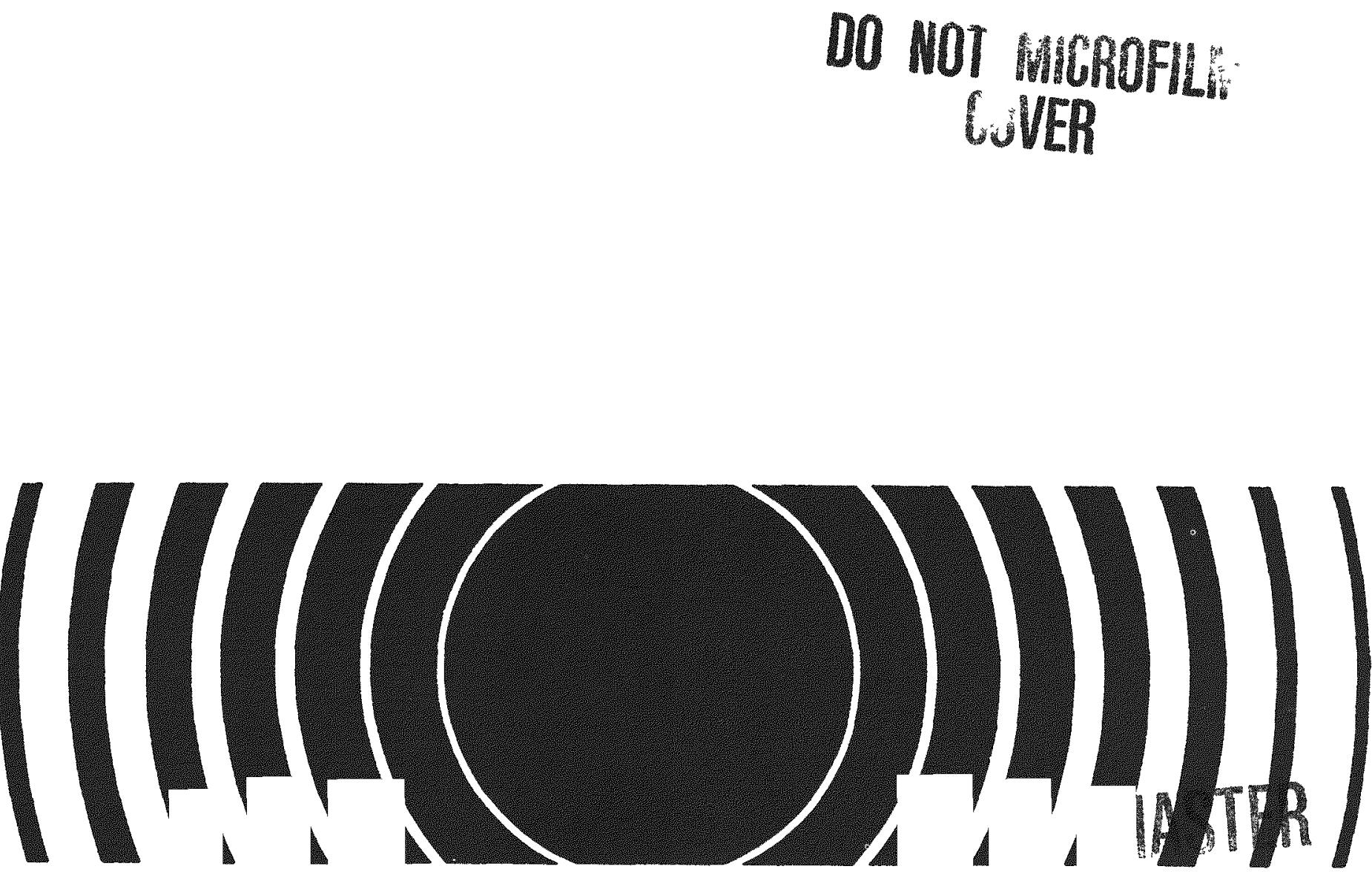

DISTRIBUTION OF THIS DOCUMENT IS UNLIMITED 


\section{DISCLAIMER}

This report was prepared as an account of work sponsored by an agency of the United States Government. Neither the United States Government nor any agency Thereof, nor any of their employees, makes any warranty, express or implied, or assumes any legal liability or responsibility for the accuracy, completeness, or usefulness of any information, apparatus, product, or process disclosed, or represents that its use would not infringe privately owned rights. Reference herein to any specific commercial product, process, or service by trade name, trademark, manufacturer, or otherwise does not necessarily constitute or imply its endorsement, recommendation, or favoring by the United States Government or any agency thereof. The views and opinions of authors expressed herein do not necessarily state or reflect those of the United States Government or any agency thereof. 


\section{DISCLAIMER}

Portions of this document may be illegible in electronic image products. Images are produced from the best available original document. 
$E P A--520 / 5-88-018$

DE89 014543

EPA $520 / 5-88-018$

\author{
Radiological Survey \\ of the \\ Mare Island Naval Shipyard, Alameda Naval Air Station, \\ and Hunters Point Shipyard
}

Mark 0. Semier

and

Richard L. Blanchard

Eastern Environmental Radiation Facility

1890 Federal Drive

Montgomery, Alabama 36109

March 1989

U.S. Environmental Protection Agency

Office of Radiation Programs

401 M Street SW

Washington DISTRIBUTI8N OF THIS DOCUNENT IS UNLMMTED 


\section{Table of Contents}

Page

List of figures .................. v

List of Tables ................ v

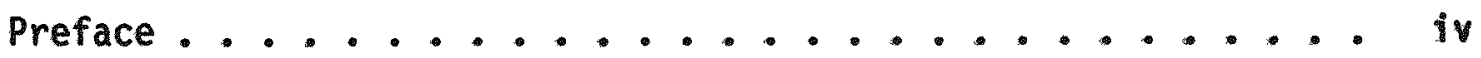

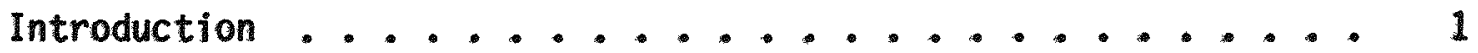

Characteristics of the Harbor and Sampling Areas ...... 3

Survey and Analytical Methods .............. 5

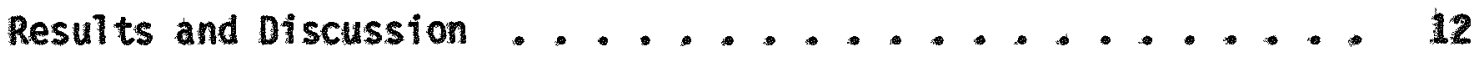

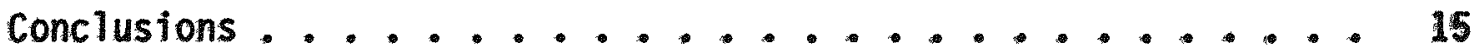

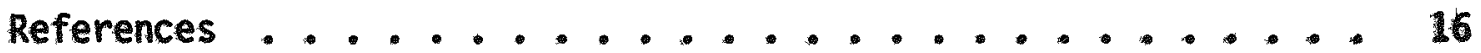

Appendix:

1. Description of Samples Collected .......... 17 


\section{List of Figures}

Figure

Page

1 General location of sites surveyed in the San Francisco

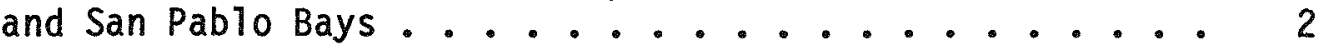

2 Sampling locations at the Mare Island Naval Shipyard.... 6

3 Sampling locations at the Alameda Naval Air Station ... . 7

4 Sampling locations at the Hunters Point Shipyard . . . . 8

\section{List of Tables}

Table

1 A summary of samples collected from the three Naval facilities ....................... 11

2 A summary of radionuclide concentrations in harbor

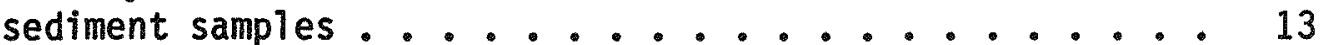

3 A summary of the gamma-ray exposure rate measurements . . 14 

and
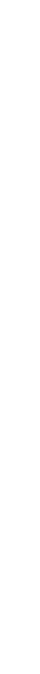

.

.

.

\author{
.
}

\author{
.
}

.

\author{
.
}

\author{
.
}

\author{
.
}

\author{
.
}

\author{
.
}

\author{
.
}

\author{
.
}

\author{
.
}

\author{
.
}

\author{
.
}

\author{
.
}

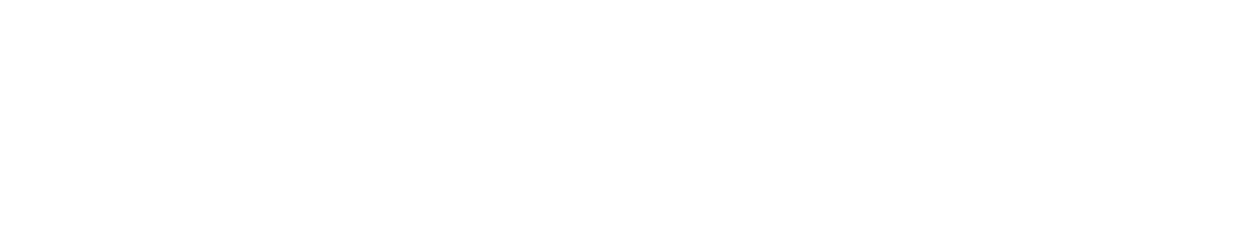

(




\section{Preface}

The Office of Radiation Programs identifies and evaluates environmental public health impacts of both natural and man-made radiation sources. The Eastern Environmental Radiation Facility (EERF) is a fully integrated participant with other components of the office in these efforts. The Facility provides comprehensive capability for evaluating radiation sources through planning and conducting environmental studies, nationwide surveillance, and laboratory analysis. The EERF also provides special analytical support for Environmental Protection Agency Regional offices and other federal government agencies, as requested, as well as technical assistance to the radiological health programs of state and local health departments.

This report presents results of surveys conducted by EERF personnel to assess levels of environmental radioactivity resulting from maintenance and operation of nuclear-powered warships at Naval facilities located within San Francisco and San Pablo Bays on the California coast. The purpose of the survey was to determine if activities related to nuclear-powered warships resulted in release of radionuclides which may contribute to significant population exposure or contamination of the environment.

Readers of our reports are encouraged to bring comments, omissions or errors to our attention.

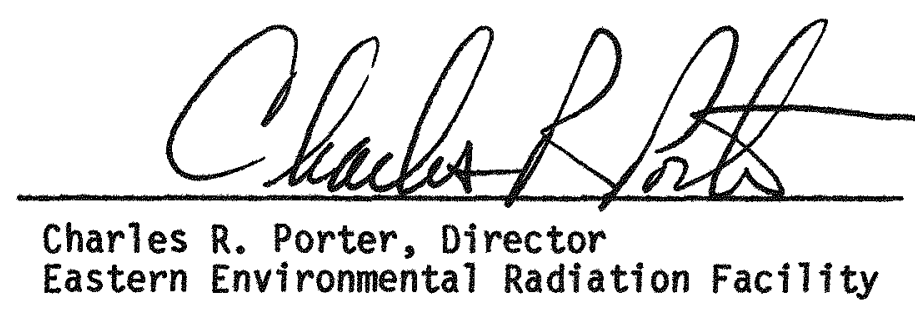


Introduction

Since 1963, the Eastern Environmental Radiation Facility (EERF), U.S. Environmental Protection Agency (USEPA), in cooperation with the U.S. Naval Sea Systems Command (NAVSEA) has surveyed facilities serving nuclear-powered warships on the Atlantic and Pacific coasts and the Gulf of Mexico. These surveys assess whether the operation of nuclear-powered warships, during construction, maintenance, overhaut, or refueling, have created elevated levels of radioactivity. The surveys emphasize sampling those areas and pathways that could expose the public.

In 1984, NAVSEA requested that EPA survey all active facilities serving nuclear-powered warships over the next three years. This report contains the results of surveys conducted at Naval facilities located at Mare Island, Alameda, and Hunters Point in the San Francisco region. The locations of these facilities are shown in Figure 1.

A previous survey was conducted in the area by EERF personnel (at that time U.S. Public Health Service) in April 1967 (Ca67). The early survey was conducted only at the Mare Island Naval Shipyard in San Pablo Bay. Radioactivity attributable to nuclear-powered warship activities, primarily $\mathrm{H}-3$ and $\mathrm{C} 0-60$, was not detected at that time in any samples collected from Mare Island Strait. Only natural radioactivity and radioactivity attributed to fallout from nuclear weapons testing was observed. The present study, conducted from September 8, 1986 to September 17, 1986, was expanded to include the Naval facilities at Alameda and Hunters Point in San Francisco Bay. 
Characteristics of the Harbor and Sampling Areas

Mare Island Strait and Vallejo

Mare Island Strait is located in the northern part of San Pablo Bay 25 miles northeast of San Francisco. The strait is formed by the city of Vallejo on the east side of the Napa River and Mare Island on the west side. Mare Island Strait is approximately three miles long and is bounded by the Sears Point Causeway on the north and San Pablo Bay on the south. The width of the strait varies from approximately one thousand to two thousand feet. The mean tidal range is 4.5 feet and the maximum current velocity is 4.1 feet per second in the strait. The bottom of the strait is characterized by soft mud and silt. Heavy silting action in the strait necessitates the removal of approximately two million cubic yards of bottom sediment annually in constant dredging operations. Over a significant portion of its length, the strait is confined between the piers and docks of Mare Island and a sea wall on the opposite shore, precluding bathing and agriculture in the vicinity of the Naval Shipyard.

The city of Vallejo has a population of approximately 80,000 . Vallejo is in a fertile agricultural section which produces grain, beets, orchard fruits, grapes and livestock. Vallejo's principal industry is the Mare Island Naval Shipyard. Since 1958 the shipyard has been involved in the construction, maintenance and overhaut of nuclear-powered warships. 
Vallejo's water supply comes from Cache Slough approximately 25 miles northeast of the city with the main pumping station at Maine Prairie Slough. There is no commercial fishing in the strait but some sport fishing is done.

Hunters Point Shipyard

The U.S. Navy Reservation at Hunters Point is located on San Francisco Bay in the southeastern sector of the city of San Francisco. Mare Island Naval Shipyard personnel occasionally perform maintenance of nuclear-powered warships at Hunters Point. The Shipyard Ties approximately three miles from the Golden Gate at the southern periphery of over 80 piers and wharves along an improved waterfront used primarily for commercial shipping enterprises. In addition to the commercial shipping enterprises carried out along the waterfront, San Francisco Bay is also used extensively for pleasure boating and limited commercial fishing activities.

Alameda Naval Air Station

The Alameda Naval Air Station is located in what is called the East Bay Area. It is on the northern end of the island occupied by the city of Alameda. It is located about two miles south of the San Francisco Oakland Bay Bridge adjacent to the towns of 0ak 1 and and Alameda and bordered by Inner Harbor and San Francisco Bay. The Alameda Naval Air Station serves as a homeport for nuclear-powered warships. 
Survey and Analytical Methods

Navy personnel helped the EERF survey team identify the most probable sampling locations, those where radioactivity associated with Naval nuclear propulsion plants, if it were present, would most likely be detected. Extensive sampling was done near the dry docks and pier areas where nuclear warships are or have been serviced. Sampling sites at the Mare Island Naval Shipyard, Alameda Naval Air Station, and Hunters Point Shipyard are shown in Figures 2, 3, and 4, respectively. Samples of bottom sediment, water, algae, sea lettuce, and mussels were collected.

According to past surveys, cobalt-60 is the predominant radioisotope one would find in environmental media if radioactivity is present as a result of Naval nuclear propulsion plant operations (Ca77, Se88); therefore, environmental sampling focused on detecting this radioisotope. Cobalt-60 content in all samples was determined by gamma-ray spectroscopy. A11 water samples were al so analyzed for tritium since this nuclide is known to be produced in the coolant of light-water nuclear reactors.

An underwater gamma scintillation probe with a 10 centimeter by 10 centimeter sodium iodide detector was used with a portable multichannel pulse height analyzer to help locate areas of radioactivity. All probe measurements were made for 10 minutes. The underwater probe has been useful in past surveys of other facilities to select areas for dredge sampling of bottom sediment and to delineate areas of radioactivity. 


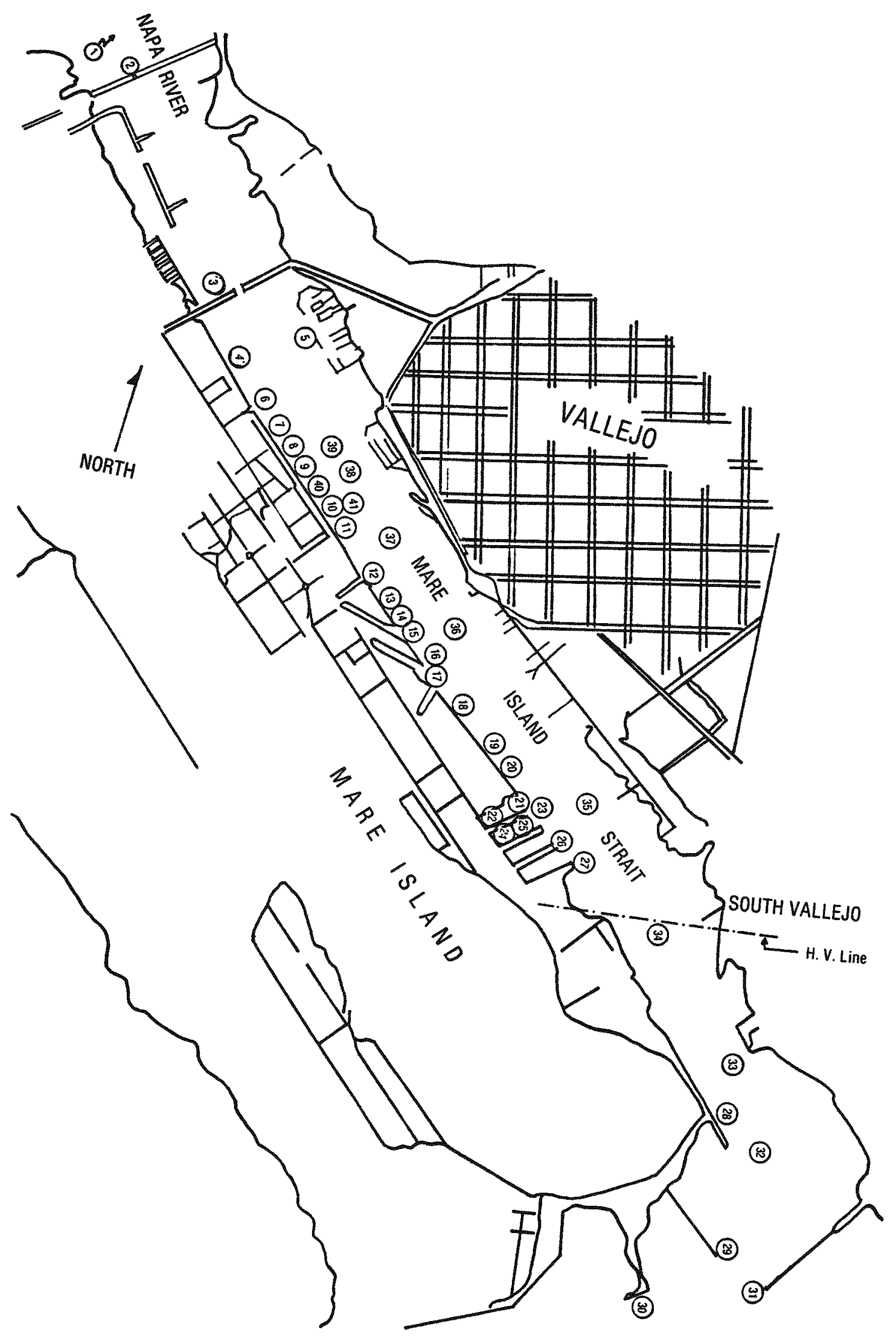

Figure 2. Sampling locations at the Mare Island Naval Shipyard. 


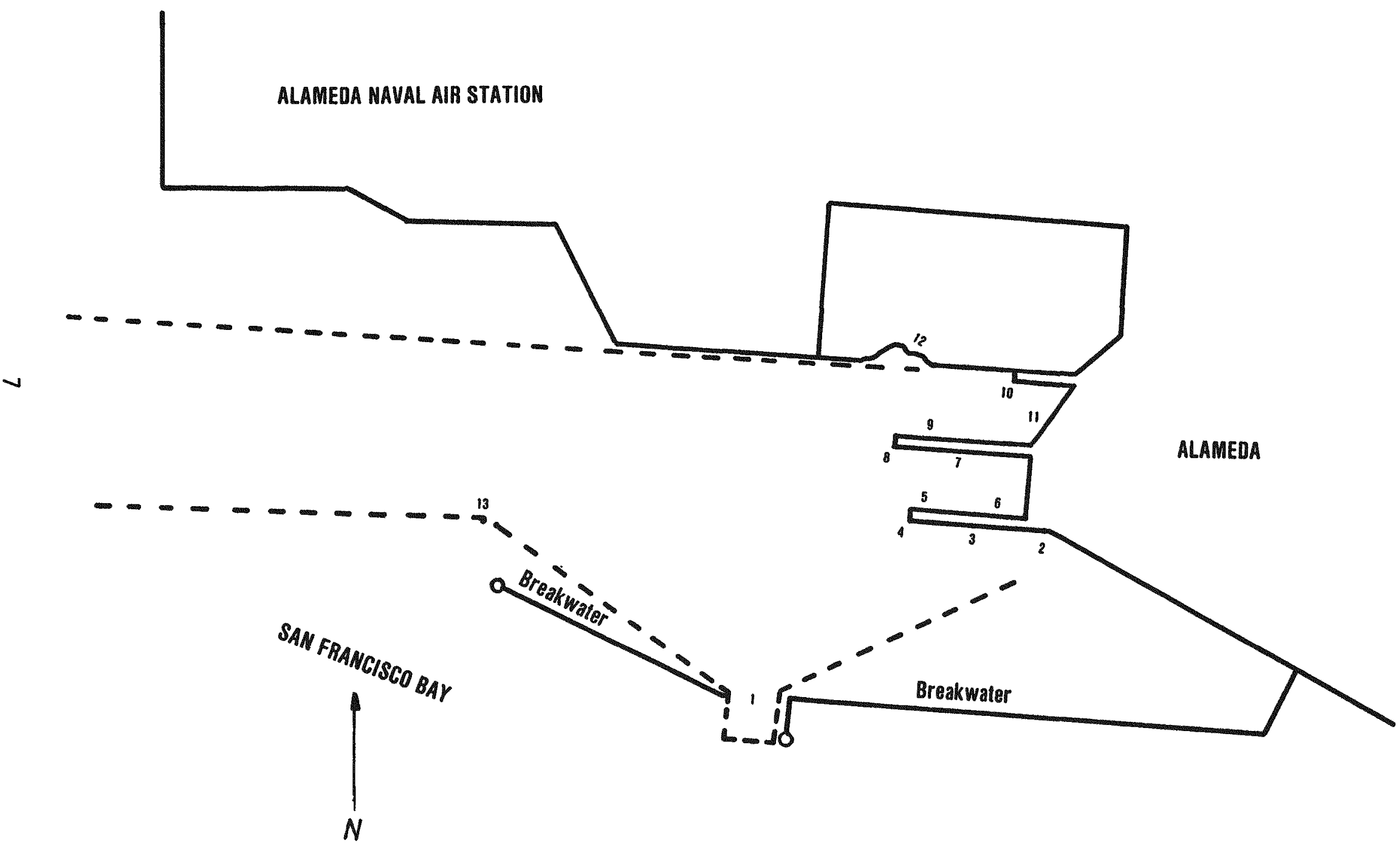




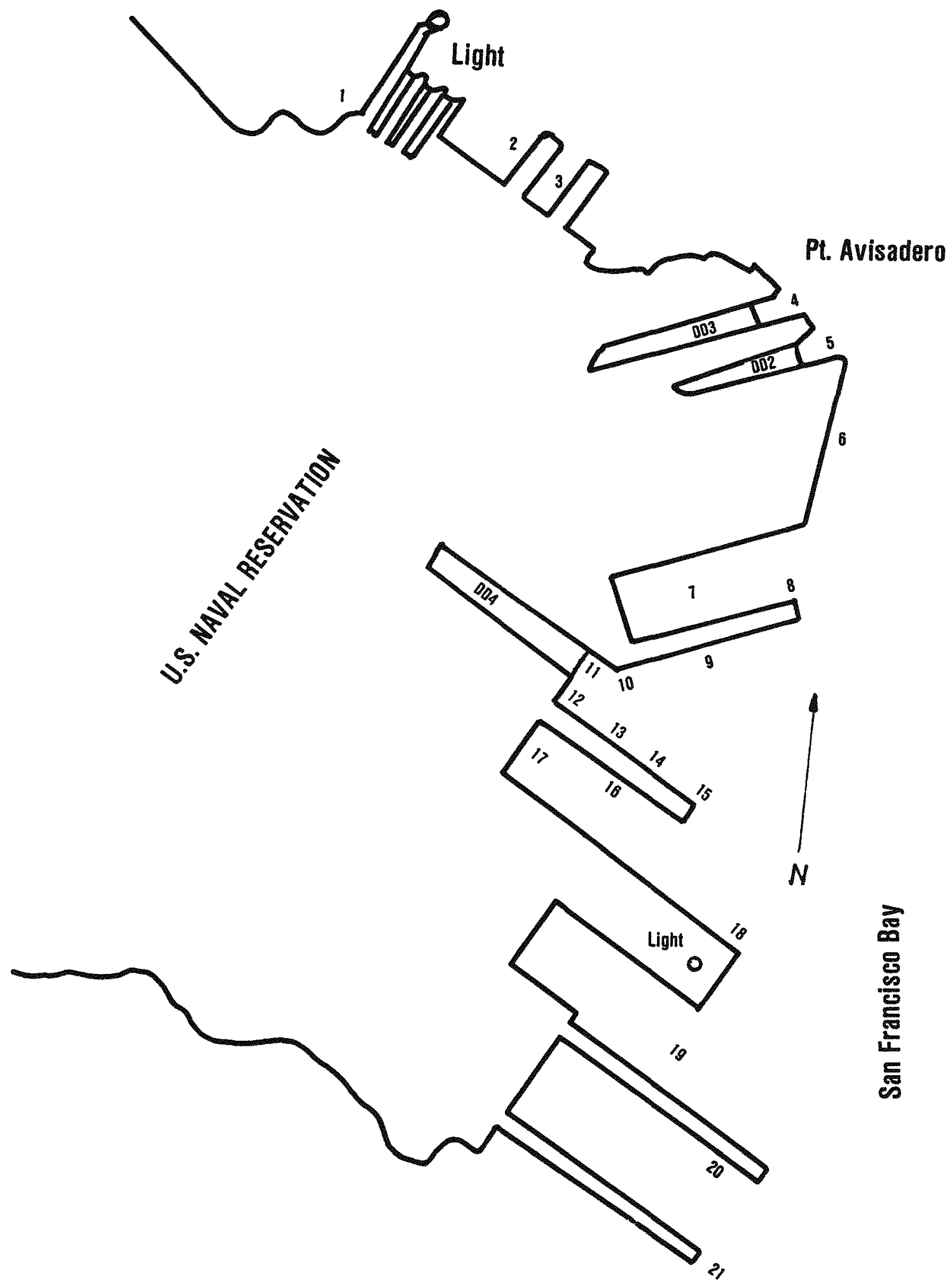

Figure 4. Sampling locations at the Hunters Point Naval Shipyard. 
However, due to the relatively low sensitivity (as compared to laboratory measurements) of the probe, sediment samples were collected at the locations of probe measurements for laboratory analysis. Duplicate samples were collected for quality assurance purposes at approximately 5 percent of the sites.

A standard Peterson dredge was used to sample approximately the top 10 centimeters of sediment. These sediment samples were collected at all locations identified in Figures 2, 3, and 4. In addition, a sediment sample was collected in a background location a few hundred yards north of the Napa Highway 37 bridge (No. 1) and at the support for the Highway 37 Bridge (No. 2). See Figure 1 for the locations of these two sampling sites. At the laboratory these samples were dried, ground to a fine powder, placed in a $400 \mathrm{~cm}^{3}$ sample counting container and counted on a $\mathrm{Ge}(\mathrm{L} i)$ or intrinsic germanium detector for 1000 minutes. The minimum detectable activity for cobalt-60 in this geometry is approximately 0.01 picocuries per gram $(\mathrm{pC} i / g)$.

Sediment core samples are useful in determining the vertical distribution of radioactivity in harbor bottom sediment. If radioactive materials were present from past operations which were subsequently covered with sediment, it might be observed in the core samples. Core samples were taken with a 3.8 centimeter diameter by 61 centimeter long plastic tube. A mechanical driver was used to push the tube into the sediment automatically capping the ends during retrieval. Core samples were collected at locations 9, 10, and 15 at the Mare Island Naval 
Shipyard and at location No. 12 at the Hunters Point Shipyard. No cores were collected from the sediments at the Alameda Naval Air Station because it had no history of past nuclear ship activities. At the laboratory the four cores were frozen and cut into $2.5 \mathrm{~cm}$ sections. The individual sections were freeze-dried and counted on a Ge(Li) or intrinsic germanium detector to determine gamma emitting radioisotopes. The minimum detectable activity for cobalt-60 in this geometry is approximately $0.1 \mathrm{pCi} / \mathrm{g}$.

Surface water samples were collected at the background location (No. 1, Figure 1) at two locations at the Mare Island Naval Shipyard (Nos. 9 and 31), at two locations at the Alameda Naval Air Station (Nos. 1 and 4), and at two locations at the Hunters Point Shipyard (Nos. 1 and 12). Public drinking water supplies were sampled at the Mare Island Naval Hospital Clinic (No. 42, Figure 1), in Vallejo at the Royal Bay Best Western Motel (No. 43, Figure 1), and at the San Francisco International Airport (No. 44, Figure 1). These samples were analyzed for gamma emitters (especially (0-60) and tritium. The minimum detectable activity for tritium and cobalt-60 in water is $200 \mathrm{pCi} / \mathrm{L}$ and $5 \mathrm{pCi} / \mathrm{L}$, respectively, with the analysis procedures used.

Algae was collected from location 15 at the Mare Island Naval Shipyard and location 2 at the Alameda Naval Air Station. Vegetation (sea lettuce) and mussel samples were collected from the harbors at the Alameda Naval Air Station and Hunters Point Shipyard. The algae and mussels were dried in an oven, then packed into $200 \mathrm{~cm}^{3}$ containers and counted dry on a $\mathrm{Ge}(\mathrm{Li})$ detector for 1,000 minutes to determine the concentrations of 
gamma emitting radioisotopes. The sea lettuce samples were treated in an identical manner, except, as a result of larger sample quantities, they were counted in $400 \mathrm{~cm}^{3}$ containers.

Gamma radiation surveys were made using pressurized ionization chambers (PIC) or portable scintillation survey instruments that were periodically calibrated with a pressurized ionization chamber. A11 measurements were made 1 meter above the ground or water surface. Surveys were conducted within the security exclusion area of the Mare Island Naval Shipyard and in the dock and pier areas of each facility where sediment (dredge) samples were collected. A summary of all samples collected from the harbors of the three facilities is presented in Table 1.

Table 1. A summary of samples collected from the three Naval facilities(a)

\begin{tabular}{lccccc}
\hline & Sampling & \multicolumn{4}{c}{ Number of Samples } \\
\cline { 4 - 6 } Facility & Sites & water & Sediment & Cores & $\begin{array}{c}\text { Aquatic } \\
\text { Life (b) }\end{array}$ \\
\hline $\begin{array}{l}\text { San Pablo Bay } \\
\begin{array}{c}\text { Mare ISland Naval } \\
\text { Shipyard }\end{array}\end{array}$ & 41 & 3 & 41 & 3 & A \\
$\begin{array}{l}\text { San Francisco Bay } \\
\text { Hunters Point Shipyard }\end{array}$ & 21 & 2 & 21 & 1 & L, M \\
Alameda Naval Air Station & 13 & 2 & 13 & 0 & A, L, M \\
\hline
\end{tabular}

(a) Samples were collected on September 8 to 11, 1986. See Appendix 1 for a listing of all samples collected at each sampling location. (b) A-algae; L-sea lettuce; M-mussels. 
Results and Discussion

Previous experience with harbor bottom sediment sampling has shown that if any significant amount of radioactivity has been released it usually would be detectable in the sediment (Ca77, Se88). Radionuclides tend to accumulate in the sediment over time which enables detection of events that may have occurred in the past. Samples were collected at 75 locations at the three Naval facilities. No cobalt-60 or other gamma emitting radionuclides from nuclear-powered warship operations were found in any of the samples. The failure of the underwater gamma scintillation probe to detect any areas on the harbor floor having radioactivity above background further confirms the absence of any significant radioactive contamination. The failure of the underwater gamma scintillation probe to detect any areas on the harbor floor having radioactivity above background further confirms the absence of any significant radioactive contamination. Only naturally occurring nuclides and trace quantities of cesium-137, typically fallout from previous worldwide nuclear weapons testing, were found in the samples. A summary of the radionuclide concentrations measured in these sediment samples is given in Table 2.

Core samples collected from 3 locations at Mare Island Naval Shipyard (Nos. 9, 10, 15) and from one location at Hunters Point Shipyard (No. 12) were analyzed for gamma emitting radionuclides. None of the eight one-inch sections from any of the four cores contained radionuclides other than those natural7y occurring and trace amounts of cesium-137, about 0.15 $\mathrm{pCi} / \mathrm{g}$ dry, that was relatively constant with depth reflecting a long-term uniform deposition rate. 
Table 2. A summary of radionuclide concentrations in harbor sediment samples

\begin{tabular}{lccccc}
\hline Radionuclide & Mare Island & Hunters Point & Alameda & Background \\
\hline Samples & \multicolumn{1}{c}{39} & 21 & 13 & 2 \\
$\mathrm{~K}-40$ & $12(8-14)$ & $12(10-15)$ & $12(9-14)$ & 11 \\
$\mathrm{C} 0-60$ & $(0.01$ & $(0.01$ & $<0.01$ & $<0.01$ \\
$\mathrm{Cs}-137$ & $0.17(0.07-0.32)$ & $0.19(0.14-0.23)$ & $0.19(0.08-0.25)$ & 0.05 \\
$\mathrm{~Pb}-214$ & $0.48(0.30-0.56)$ & $0.42(0.36-0.52)$ & $0.42(0.32-0.49)$ & 0.60 \\
$\mathrm{Bi}-214$ & $0.46(0.29-0.52)$ & $0.40(0.35-0.51)$ & $0.40(0.31-0.48)$ & 0.56 \\
$\mathrm{Ra}-226$ & $1.1(0.8-1.4)$ & $0.99(0.80-1.11)$ & $1.4(0.71-1.15)$ & 1.4 \\
$\mathrm{Th}-232$ & $0.46(0.32-0.55)$ & $0.38(0.29-0.42)$ & $0.37(0.26-0.43)$ & 0.73 \\
\hline
\end{tabular}

Notes:

1) Concentrations are $\mathrm{PCi} / \mathrm{g}$ dry weight.

2) Mean concentrations are given with the range shown in parentheses.

3) Approximate $2 \sigma$ counting errors are:

K-40 (3 percent); Cs-137 (10 percent); Pb-214 (7 percent); Bi-214

(7 percent); Ra-226 (20 percent); Th-232 (11 percent).

Surface water samples collected in the harbors at Mare Island, Hunters Point, and Alameda had tritium levels below the minimum detectable level of $200 \mathrm{pCi} / \mathrm{L}$. Potassium-40, a naturally occurring radionuclide and present at an average concentration of $230 \pm 60 \mathrm{pCi} / \mathrm{L}$, was the only gamma emitting nuclide detected. Also, no detectable radioactivity was found in the three drinking water samples from the water supplies of Mare Island, Vallejo, and San Francisco.

Only very small quantities of naturally occurring radionuclides, principally $\mathrm{K}-40$ (about $30 \mathrm{pCi} / \mathrm{g}$ dry), and Cs-137 ( $0.1 \mathrm{pCi} / \mathrm{g}$ dry) typical of fallout from previous nuclear weapons testing, were measured in samples of algae collected in the harbors at Alameda and Mare Island. Smaller quantities of these radionuclides were observed in the two sea 
lettuce samples from the harbors at Alameda and Hunters Point. Both mussel samples contained only $\mathrm{K}-40$ (10 pCi/g dry) and a trace of $\mathrm{Cs}-137(0.02 \mathrm{pCi} / \mathrm{g}$ dry). Thus, no radioactivity indicative of nuclear-powered ships was detected in any of the biological samples that were collected from the harbors.

A summary of the gamma-ray exposure rates measured at each sampling location in the harbors of the three Naval facilities (see Figures 2, 3, and 4 ) is given in Table 3 . The exposures were relatively constant over the surface of the harbors, varying only within a small range. The average exposure rate at all three facilities was $4.4 \pm 0.4 \mu \mathrm{R} / \mathrm{hr}$, which is consistent with that measured in nearby background areas, $4.1 \pm 0.2 \mu \mathrm{R} / \mathrm{hr}$. The gamma-ray exposure rate was also measured in the security exclusion zone of the Mare Island Naval Shipyard on September 8, 1986. The gamma-ray survey began at the causeway and proceeded south at 2-3 knots remaining about 100 yards off the piers. The gamma-ray exposure rates varied from 3.5 to $5.0 \mu \mathrm{R} / \mathrm{hr}$ with an average of $4.0 \mu \mathrm{R} / \mathrm{hr}$. These exposure rates again reflect natural background levels.

Table 3. A summary of the gamma-ray exposure rate measurements

\begin{tabular}{|c|c|c|c|}
\hline Location of Survey & $\begin{array}{c}\text { No. of } \\
\text { Measurements } \\
\end{array}$ & $\frac{\text { Gamma-Ray Exposure }}{\text { Average }^{(b)}}$ & $\frac{\text { Rates, } \mu \mathrm{R} / \mathrm{hr}(\mathrm{a})}{\text { Range }}$ \\
\hline Mare Island Naval Shipyard & 41 & $4.4 \pm 0.5$ & $3.4-5.8$ \\
\hline Alameda Naval Air Station & 21 & $4.4 \pm 0.3$ & $3.9-5.0$ \\
\hline Hunters Point Shipyard & 13 & $4.4 \pm 0.4$ & $3.6-5.0$ \\
\hline
\end{tabular}

(a) Background exposure rate was $4.1 \pm 0.2$.

(b) \pm values are the standard deviation of the means. 


\section{Conclusions}

The radiological survey of the Mare Island Naval Shipyard, Alameda Naval Air Station, and Hunters Point Shipyard provided the basis for the following conclusions:

1. Only radionuclides of natural origin and trace amounts of Cs-137 from previous nuclear weapons testing were detected in the harbor sediment samples. No radioactivity associated with the operation and maintenance of nuclear-powered warships was detected in any of either the dredge or core sediment samples.

2. No tritium or gamma-ray emitters, other than trace amounts of those occurring naturally, were detected in surface water from the harbors or in nearby drinking water supplies.

3. No gamma-ray emitters, other than trace amounts of those occurring naturally, were detected in harbor algae, mussels, or sea lettuce.

4. Gamma-ray surveys of the harbors failed to detect any exposure rates elevated significantly above background.

5. Based on this survey, operations related to nuclear-powered warship activities have contributed no detectable radioactivity to the harbors at Mare Island, Alameda, and Hunters Point. Thus, under present conditions Naval operations within these harbors pose no radiological health problem to the public. 


\section{References}

Ca67 Cahil1, D.F., McCurry, D.C., and Breakfield, W.D., 1967, "Radiological Survey of Major California Nuclear Ports-April 1967", U.S. Public Health Service, Southeastern Environmental Radiological Health Laboratory Report, PB-178-728.

Ca77 Callis, R.S., Windham, S.T., and Phillips, C.R., 1977, "Radiological Survey of Puget Sound Naval Shipyard, Bremerton, Washington and Environs", U.S. Environmental Protection Agency Report, EPA 520/5-77-001.

Se88 Sensintaffar, E.L. and Blanchard, R.L., 1988, "Radiological Survey of the Norfolk Naval Station, the Norfolk Naval Shipyard, and Newport News Shipbuilding", U.S. Environmental Protection Agency Report, EPA 520/5-88-017. 
APPENDIX 1

Description of Samples Collected

\begin{tabular}{|c|c|c|c|}
\hline $\begin{array}{l}\text { Sampling } \\
\text { Site No. }\end{array}$ & Samples Collected & $\begin{array}{l}\text { Sampling } \\
\text { Site No. }\end{array}$ & Samples Collected \\
\hline \multicolumn{4}{|c|}{ Mare Island Naval Shipyard } \\
\hline $\begin{array}{l}1 \\
2 \\
3 \\
4 \\
5 \\
6 \\
7 \\
8 \\
9 \\
\\
10 \\
11 \\
12 \\
13 \\
14 \\
15 \\
16 \\
17 \\
18 \\
19 \\
20 \\
21\end{array}$ & $\begin{array}{l}\text { Sediment, surface water } \\
\text { Sediment } \\
\text { Sediment } \\
\text { Sediment } \\
\text { Sediment } \\
\text { Sediment } \\
\text { Sediment } \\
\text { Sediment } \\
\text { Sediment, core, } \\
\text { surface water } \\
\text { Sediment, core } \\
\text { Sediment } \\
\text { Sediment } \\
\text { Sediment } \\
\text { Sediment } \\
\text { Sediment, core, algae } \\
\text { Sediment } \\
\text { Sediment } \\
\text { Sediment } \\
\text { Sediment } \\
\text { Sediment } \\
\text { Sediment }\end{array}$ & $\begin{array}{l}22 \\
23 \\
24 \\
25 \\
26 \\
27 \\
28 \\
29 \\
30 \\
31 \\
32 \\
33 \\
34 \\
35 \\
36 \\
37 \\
38 \\
39 \\
40 \\
41 \\
42 \\
43\end{array}$ & $\begin{array}{l}\text { Sediment } \\
\text { Sediment } \\
\text { Sediment } \\
\text { Sediment } \\
\text { Sediment } \\
\text { Sediment } \\
\text { Sediment } \\
\text { Sediment } \\
\text { Sediment } \\
\text { Sediment, surface water } \\
\text { Sediment } \\
\text { Sediment } \\
\text { Sediment } \\
\text { Sediment } \\
\text { Sediment } \\
\text { Sediment } \\
\text { Sediment } \\
\text { Sediment } \\
\text { Sediment } \\
\text { Sediment } \\
\text { Drinking water } \\
\text { Drinking water }\end{array}$ \\
\hline \multicolumn{4}{|c|}{ Alameda Naval Air Station } \\
\hline $\begin{array}{l}1 \\
2 \\
3 \\
4 \\
5 \\
6 \\
7\end{array}$ & $\begin{array}{l}\text { Sediment, surface water } \\
\text { Sediment, algae } \\
\text { Sediment } \\
\text { Sediment, surface water } \\
\text { Sediment } \\
\text { Sediment } \\
\text { Sediment }\end{array}$ & $\begin{array}{l}8 \\
9 \\
10 \\
11 \\
12 \\
13 \\
\text { (a) } \\
\text { (b) }\end{array}$ & $\begin{array}{l}\text { Sediment } \\
\text { Sediment } \\
\text { Sediment } \\
\text { Sediment } \\
\text { Sediment } \\
\text { Sediment } \\
\text { Sea Lettuce } \\
\text { Mussels }\end{array}$ \\
\hline
\end{tabular}


APPENDIX 1 - Continued

Description of Samples Collected

\begin{tabular}{|c|c|c|c|}
\hline $\begin{array}{l}\text { Sampling } \\
\text { Site No. }\end{array}$ & Samples Collected & $\begin{array}{l}\text { Sampling } \\
\text { Site No. }\end{array}$ & Samples Collected \\
\hline & \multicolumn{2}{|c|}{ Hunters Point Naval Shipyard } & \\
\hline $\begin{array}{r}1 \\
2 \\
3 \\
4 \\
5 \\
6 \\
7 \\
8 \\
9 \\
10 \\
11 \\
12\end{array}$ & $\begin{array}{l}\text { Sediment, surface water } \\
\text { Sediment } \\
\text { Sediment } \\
\text { Sediment } \\
\text { Sediment } \\
\text { Sediment } \\
\text { Sediment } \\
\text { Sediment } \\
\text { Sediment } \\
\text { Sediment } \\
\text { Sediment } \\
\text { Sediment, core, surface water }\end{array}$ & $\begin{array}{l}13 \\
14 \\
15 \\
16 \\
17 \\
18 \\
19 \\
20 \\
21 \\
44 \\
\text { (a) } \\
\text { (b) }\end{array}$ & $\begin{array}{l}\text { Sediment } \\
\text { Sediment } \\
\text { Sediment } \\
\text { Sediment } \\
\text { Sediment } \\
\text { Sediment } \\
\text { Sediment } \\
\text { Sediment } \\
\text { Sediment } \\
\text { Drinking water } \\
\text { Sea lettuce } \\
\text { Mussels }\end{array}$ \\
\hline
\end{tabular}

(a) Samples of sea lettuce were floating.

(b) Collected from multiple sites across the harbor. 